\title{
Caseinase Production and Media Optimization from Bacillus subtilis
}

\author{
NOOR NIHAD ABDUL HUSSEIN ${ }^{1}$, ASEEL I. IBRAHIM ${ }^{1}$, FIRAS HASHIM KAMAR ${ }^{2}$, \\ AURELIA CRISTINA NECHIFOR ${ }^{3 *}$ \\ ${ }^{1}$ Department of Clinical Laboratory Science, College of Pharmacy, University of Baghdad, Baghdad, Iraq \\ ${ }^{2}$ Engineering Technical College, Middle Technical University, Baghdad, Iraq \\ ${ }^{3}$ University Politehnica of Bucharest, Department of Analytical Chemistry and Environmental Engineering, 1-7 Gheorghe \\ Polizu, Str., 011061, Bucharest, Romania
}

\begin{abstract}
Caseinase is involved in the breakdown of milk protein casein and converts casein into smaller simple sugars which can be easily utilized by the body for the production of ATP and Fat. Casein can be an instant energy source to the body and involves in muscle building. Caseinase enzyme can be extensively used at the industrial scale for Milk, Textile, Dairy, Paper industry and several other medical purposes. In view of the importance of caseinase, the current research deals with the isolation and identification of caseinase producing bacteria from soil. This is followed by the production of enzyme and its purification. The study also includes its kinetic characterization using the parameters Temperature, $\mathrm{pH}$ as well as Carbon and Nitrogen Sources. The organism which was isolated from soil and capable of producing the caseinase enzyme was identified to be Bacillus subtilis based on the Biochemical tests and I6S rRNA sequencing result. The optimal carbon and nitrogen sources were identified to be Glucose and casein respectively. Regarding the optimal conditions, the suitable temperature for maximum enzyme production was found to be $40^{\circ} \mathrm{C}$ and $\mathrm{pH}$ was 9 . When the organism was cultured under the optimal condition using casein as a nitrogen source and glucose as the carbon source, at $40^{\circ} \mathrm{C}$ and $\mathrm{pH} 9,1590 \mathrm{ng} / \mathrm{mL}$ of enzyme production was estimated.
\end{abstract}

Keywords: Caseinase, Bacillus subtilis, kinetic characterization, $16 S$ rRNA sequencing

\section{Introduction}

Casein is the major protein of the milk constituting for about $90 \%$ of its composition. It has extensive nutritional value. This is the major protein present in the dairy products like cheese, paneer etc. Caseinase, a natural exoenzyme secreted by several bacteria, hydrolyzes the casein protein and converts it to simple soluble form. Several groups of bacteria are known for their ability to release the enzyme caseinase thus utilizing the casein protein [1]. Several studies were conducted even at the genetic level to extract the gene encoding for caseinase activity. microbial proteases as industrial catalysts offer advantages over the use of conventional chemical catalysts for economically viable, exhibiting high catalytic activity, high degree of substrate specificity, and can be produced in huge amounts etc. [2]. Bacteria appear to be relatively simple life forms. In fact, they are bodies with an incredible degree of adaptation, which involves complexity. Many bacteria multiply to very high speeds, and different species may use as food a huge variety of organic substances [3].

One such study was carried on by Blaschek and Solberg, who published their work in The Journal of Bacteriology [4]. According to their research Clostridium perfringens strain ATCC 3626B was cured of caseinase activity at a high frequency after treatment with acriflavine dye $(2.5 \%)$ or elevated temperature growth $(9.1 \%)$. The team has done a genetic analysis to isolate the plasmid encoding for caseinase activity. Another study was related to the hemolytic activity of Bacterial species, a fish pathogen Aeromonas salmonicida, based on its caseinase enzyme. This study was conducted by Titball and published in the Journal of Infection and Immunity [5]. In this study, it was analyzed that the mutants of this bacteria which were incapable to utilize the casein protein also lost their ability to perform haemolysis of horse blood, showing an association between the two genes.

\footnotetext{
*email:aureliacristinanechifor@gmail.com
} 
In most of the studies caseinase gene can be used as a marker for the identification of various gene traits that occur together with this gene. Esp gene carriage in enterococci occurs together with the caseinase gene. This special property has been used to develop a PCR independent assay for esp gene based on the study of caseinase gene [6]. This study was reported in AIP Conference Proceedings 1571, 202 (2013). For the identification of these caseinase positive traits casein agar has been employed. Organisms like Streptomyces, Pseudomonas, and Actinomadura spp. which can hydrolyse casein will produce a clear halo in the surrounding medium [7], indicating the utilization of casein from the media.

\section{Materials and methods}

\subsection{Sample Collection}

Since soil is known to possess a wide variety of bacteria in which the possibility of obtaining the required bacteria is high, it is selected as the source for the isolation of organisms [8]. Those organisms that are cable of utilizing the casein protein by releasing caseinase are required for the study. Sub surface soil has been collected from the ground near the root system of the plants. The soil is later subjected for serial dilution and plating.

\subsection{Bacterial Isolation}

The 10 fold dilution technique [9] can be used for serial dilution. Nutrient agar medium containing the basic carbon source as glucose, minerals and micronutrients as $\mathrm{NaCl}$ and yeast extract, amino acids in the form of peptone was prepared for plating using the standard composition. Agar-Agar was used as a solidification agent. Spread plate technique was to be employed to obtain all species of bacteria onto a common plate as isolated colonies. The spread plates were incubated for $24 \mathrm{~h}$ at $37^{\circ} \mathrm{C}$ in an incubator for the microbial growth. For obtaining the pure culture $100 \mathrm{~mL}$ of Nutrient Agar media was once again prepared and autoclaved. From the master plate four morphologically different colonies were picked and inoculated on four petri plates by quadrant streaking [10].

\subsection{Screening for Caseinase Production}

Once all the bacteria have been isolated as pure cultures they need to be tested for the caseinase activity. The special media have to be used for this purpose. The media would contain all the components similar to nutrient agar media except for the carbon source. Rather than using Glucose as the carbon source. Casein has to be used in this screening [11], Abou El-Hassayeb and Abdel Aziz explained that the addition other sources of carbon except starch in the production medium caused remarkable decreases in protease production by $B$. subtilis [12]. Only those organisms which can utilize casein as the carbon source can grow in the screening media, as here is no other simple carbon source which can be utilized. Carbon source plays important role in the enzyme production and different bacteria utilized different C-source for their growth and metabolism [13]. Thus the media would allow the growth of selectively those organisms which are capable of producing caseinase. Thus a screening media plate would contain only those selected bacteria which possess the required quality which is tested for. These bacteria are to be further subcultured so as to obtain pure cultures of the positive bacteria, Positive caseinolytic activity was detected by the formation of a turbidity zone (white halo) surrounding the well (12 $\mathrm{mm}$ or more) [14].

\subsection{Identification of Caseinase Producing Bacteria}

The basic protocol and the first step for the identification of any bacterial species is the Gram's staining [15]. The bacterium that has been selected for its capability to produce caseinase enzyme has to be identified for further study. Gram staining was performed for the sample and the results were analyzed. Furthermore, Bergey's Manual [16] has been used for the various biochemical tests that have to be performed in series for the identification of the bacteria. Based on the nature of gram's stain the bacteria can be subjected for various biochemical tests. The biochemical tests performed for caseinase 
positive bacteria were Starch Hydrolysis Test [17], Voges Proskauer test [18], simmon's citrate test [19] and growth in $6.5 \% \mathrm{NaCl}$. All the results are recorded before processing for the next test in the series.

\subsection{Molecular Characterization for Bacterial Identification}

Following procedure was adopted for Bacterial identification by 16S rRNA Sequencing:

\subsubsection{Extraction of DNA from Bacteria}

The cell suspension was made from the pure culture for DNA extraction. In this protocol lysis buffer containing Tris $\mathrm{HCl}$, EDTA, $\mathrm{NaCl}$, proteinase $\mathrm{K}$ and SDS [20] is initially added to break down the cell wall and expose the internal cell contents outside. Centrifugation helped to separate the cell contents from one another. Ethanol precipitation assisted in the separation of DNA from the solution. The separated DNA is further purified by ethanol wash and preserved at $4{ }^{\circ} \mathrm{C}$.

\subsubsection{Agarose Gel Electrophoresis}

In order to confirm the presence of DNA and its quality the separated DNA was subjected to electrophoresis in 0.8\% Agarose Gel [21]. Here the tracking dye used was Bromophenol blue [22] and Ethidium bromide [23] was used for visualizing the DNA under UV. The gel was run for 30 min at 100 $\mathrm{V}$ and observed under the UV Trans illuminator.

\subsubsection{Amplification and Sequencing}

In order to identify the bacteria at the molecular level amplification was performed using polymerase chain reaction [24] to obtain amplicons which can be used for sequencing.

Note: The primers used for the amplification of 16S rRNA gene.

- F AGA GTT TGA TCC TGG CTC AG

- R ACG GCT ACC TTG TTA CGA CTT

PCR Conditions which are required for amplification:

1 cycle: $94^{\circ} \mathrm{C}$ for $5 \mathrm{~min}$ (Initial denaturing)

35 cycles: $94^{\circ} \mathrm{C}$ for $30 \mathrm{~s}$ (denaturing)

$55^{\circ} \mathrm{C}$ for $30 \mathrm{~s}$ (annealing)

$72^{\circ} \mathrm{C}$ for $30 \mathrm{~s}$ (extension)

1 Cycle: $72^{\circ} \mathrm{C}$ for 7 min (final extension)

Amplified PCR product was subjected to electrophoresis using 1\% Agarose in TAE buffer and $1 \mathrm{~kb}$ ladder as marker and visualized by staining with ethidium bromide. 3730XL ABI sequencer, an automated sequencing device [25] based on capillary electrophoresis has been used for reading the sequence of the amplicons provided.

\subsubsection{BLAST for Sequence Identification}

The similarity search of the obtained sequence was done using BLAST. With the user entered sequence the tool performs a pair wise similarity search based on Needleman - Wunsch algorithm and the sequence is compared against a set of sequences from the database. This comparison with the database sequences yield an insight to the identity of the sequence.

\subsection{Media Standardization for Enzyme Production}

In order to analyze the best media composition for the maximum yield of enzyme various media compositions have been tested. The caseinase producing bacteria was inoculated in media of different carbon sources, the enzyme produced was obtained after centrifugation, OD was measured in spectrophotometer at $595 \mathrm{~nm}$ and its concentration was determined by plotting a graph against standard OD vs enzyme concentration. Carbon sources tested were Glucose, Mannitol, Fructose, Lactose and Sucrose. In each case the enzyme produced was further evaluated for its concentration determination. The results are further graphically represented and compared. Similarly a comparative study of various 
nitrogen sources on enzyme production was undertaken. Different nitrogen sources tested were Casein, Peptone, Sodium Nitrate, Urea and Ammonium Sulphate. The production of enzyme requires an optimum standard temperature of incubation and $p \mathrm{H}$. In the current work the optimum temperature and $p \mathrm{H}$ required were studies by keeping their varying values.

\subsection{Purification of the Enzyme Produced}

The protein produced above is crude and contains several impurities which have to be removed. Thus the crude extract has to be subjected for several purification techniques to obtain a pure enzyme. Salt Precipitation was performed by adding Ammonium sulphate [26] upto 80\% saturation into the crude enzyme under ice cold conditions and incubated at $4^{\circ} \mathrm{C}$ overnight. This grabs all the protein into its precipitate form that settles as a salt in the bottom of the beaker. After incubation to collect the pure protein the mixture has to be centrifuged at $10,000 \mathrm{rpm}$ for $10 \mathrm{~min}$. The pellet obtained was subjected for dialysis in activated nitrocellulose membranes kept on magnetic stirrer overnight.

\subsection{Sodium DodecylSulphate Polyacrylamide Gel Electrophoresis}

Molecular weight determination by Sodium dodecyl sulfate polyacrylamide gel electrophoresis (SDS-PAGE) was carried out in a 3-mm slab gel.

Polyacrylamide separating gel (12\%) that consists of $30 \%$ acrylamide mixture, $1.5 \mathrm{M}$ Tris- $\mathrm{HCl}$ buffer, $p \mathrm{H} \mathrm{8.8,10 \%} \mathrm{SDS} \mathrm{(w/v),} \mathrm{10 \%} \mathrm{(w/v)} \mathrm{ammonium} \mathrm{per} \mathrm{sulfate} \mathrm{and} \mathrm{TEMED.} \mathrm{It} \mathrm{was} \mathrm{prepared} \mathrm{by}$ mixing $1.68 \mathrm{~mL}$ of water, $2 \mathrm{~mL}$ of $30 \%$ acrylamide mixture, $1.25 \mathrm{~mL}$ of $1.5 \mathrm{M}$ Tris- $\mathrm{HCl}(p \mathrm{H} 8.8), 50$ $\mu \mathrm{L}$ of $10 \%$ SDS, $25 \mu \mathrm{L}$ of $10 \%$ ammonium per sulfate and lastly $2.5 \mu \mathrm{L}$ of TEMED to final volume of $5 \mathrm{~mL}$.

Stacking gel (4\%)- It was prepared by mixing $3.05 \mathrm{~mL}$ of water, $665 \mu$ of $30 \%$ acrylamide mixture, $1.25 \mu \mathrm{L}$ of $0.5 \mathrm{M}$ Tris- $\mathrm{HCl}(p \mathrm{H} 6.8), 50 \mu \mathrm{L}$ of $10 \% \mathrm{SDS}, 25 \mu \mathrm{L}$ of $10 \%$ ammonium per sulfate and lastly $5 \mu \mathrm{L}$ of TEMED to final volume of $5 \mathrm{~mL}$. The gels were stained with Coomassie brilliant blue R250 and destained. The standard proteins with a range of 3-35 KDa weight were used as the marker.

\section{Results and discussions}

\subsection{Screening for Protease Production}

The four pure cultures showed good growth after $24 \mathrm{~h}$ of incubation and subjected for screening of caseinase production. Figure 1 shows one of the bacterial isolates showed positive result with a clear transparent zone around the colony. Gelatinase hydrolysis is used as an interchangeable term for caseinase activity [27], where gelatinase is extracellular zinc-endopeptidase that capable for gelatinase hydrolysis, collagen, casein and other active peptides [28].
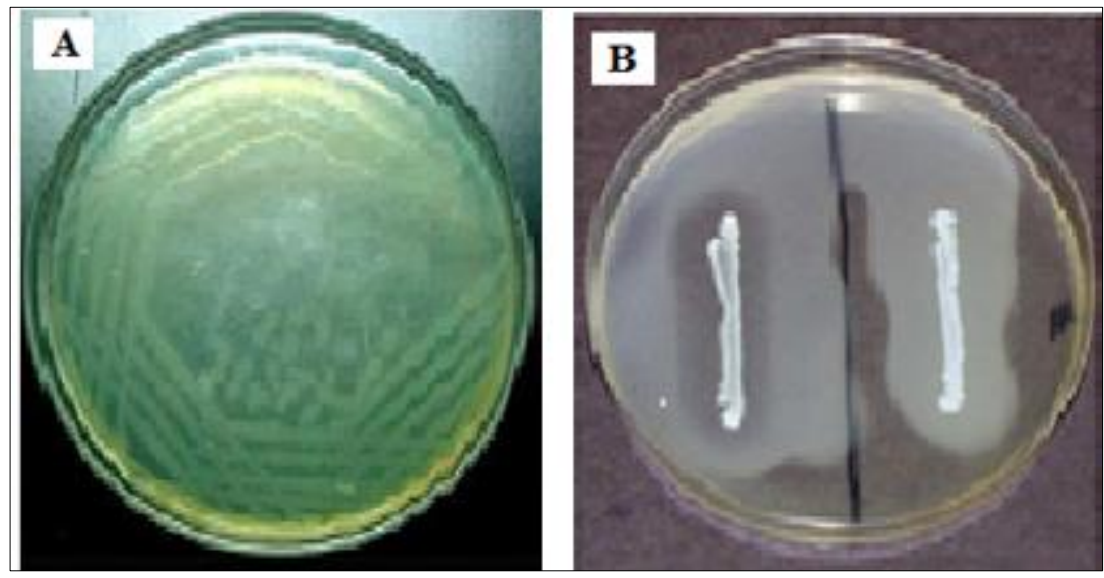

Figure 1. Pure culture and screening results

A- Test culture, Bacillus Sample,

B- Demonstration of Negative result in a sample 


\subsection{Biochemical Identification of Bacteria}

The colony morphology, Gram's staining nature and biochemical tests' response of the positively screened bacteria [29] as shown in the Table 1.

Table 1. Biochemical characterization of caseinase producing test bacteria

\begin{tabular}{|ccc|}
\hline S. No & Test & Observation \\
\hline 1 & Gram's Staining & Gram Positive Bacilli \\
2 & Starch Hydrolysis & Positive for Amylase \\
3 & Voges Proskaver test & Positive \\
4 & Simmon's citrate Test & Positive \\
5 & Growth in $6.5 \% \mathrm{NaC} 1$ & Positive \\
\hline
\end{tabular}

\subsection{Amplification and Sequence Similarity}

The amplicons obtained for 16S rRNA gene were found to be of approx $1500 \mathrm{bp}$ length as shown in Figure 2.

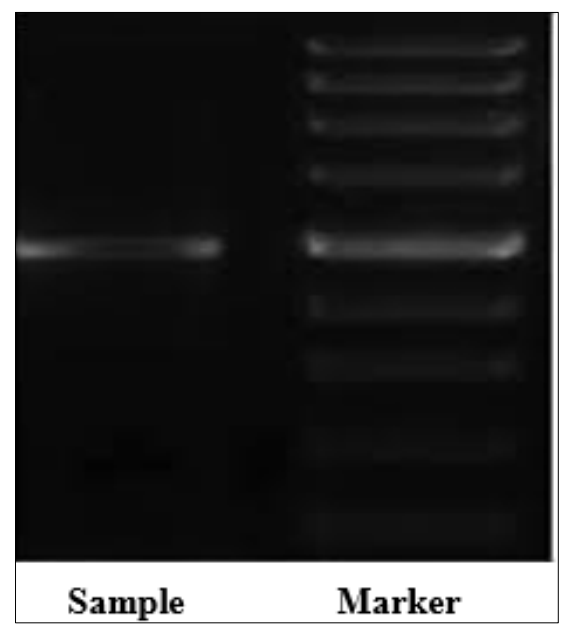

Figure 2. Gel Picture of the amplicon

Figure 3 shows the sequence obtained were identified as of Bacillus subtilis strain DUCC3714 16S ribosomal RNA gene, partial sequence.

AAGGTTTTCGGATCGTAAAGCTCTGTTGTTAGGGAAGAACAAGTACCGTTCGAATAG GGCGGTACCTTGACGGTACCTAACCAGAAAGCCACGGCTAACTACGTGCCAGCAGCC GCGGTAATACGTAGGTGGCAAGCGTTGTCCGGAATTATTGGGCGTAAAGGGCTCGCA GGCGGTTTCTTAAGTCTGATGTGAAAGCCCCCGGCTCAACCGGGGAGGGTCATTGGA AACTGGGGAACTTGAGTGCAGAAGAGGAGAGTGGAATTCCACGTGTAGCGGTGAAA TGCGTAGAGATGTGGAGGAACACCAGTGGCGAAGGCGACTCTCTGGTCTGTAACTGA CGCTGAGGAGCGAAAGCGTGGGGAGCGAACAGGATTAGATACCCTGGTAGTCCACG CCGTAAACGATGAGTGCTAAGTGTTAGGGGGTTTCCGCCCCTTAGTGCTGCAGCTAA CGCATTAAGCACTCCGCCTGGGGAGTACGGTCGCAAGACTGAAACTCAAAGGAATTG ACGGGGGCCCGCACAAGCGGTGGAGCATGTGGTTTAATTCGAAGCAACG.

Note: The assembled DNA sequence was used to carry out BLAST with the nrdatabase of NCBI. BLAST Reference

\begin{tabular}{|ccccc|}
\hline Score & Expect & Identities & Gaps & Strand \\
\hline 1035 bits (560) & 0.0 & $560 / 560(100 \%)$ & $0 / 560(0 \%)$ & Plus $/$ Plus \\
\hline
\end{tabular}

Figure 3. Sequence of Bacillus subtilis strain DUCC3714 16S ribosomal RNA gene, partial sequence 


\subsection{Media Optimization}

Based on the concentration obtained Figures 4 to 7 it was found that the enzyme yield was highest with Glucose as a carbon source and casein as the nitrogen source indicated by their respective highest $\mathrm{OD}$ values. The optimum temperature and $p \mathrm{H}$ for the maximum enzyme yield were found to be $40^{\circ} \mathrm{C}$ and $p \mathrm{H}$ 9. Thus, maintaining the above conditions with standard media composition shown in Table 2 would provide the highest yield of caseinase from Bacillus subtilis strain DUCC3714.

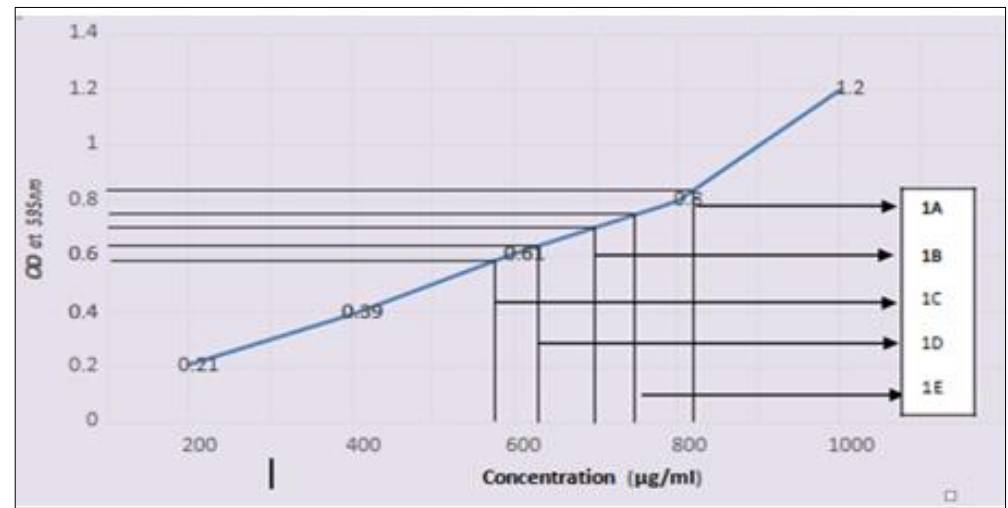

Figure 4. Effect of varying carbon sources on enzyme production $1 \mathrm{~A}=$ Glucose; $1 \mathrm{~B}=$ Mannitol; $1 \mathrm{C}:$ Lactose; $1 \mathrm{D}=$ Sucrose; $1 \mathrm{E}=$ Fructose

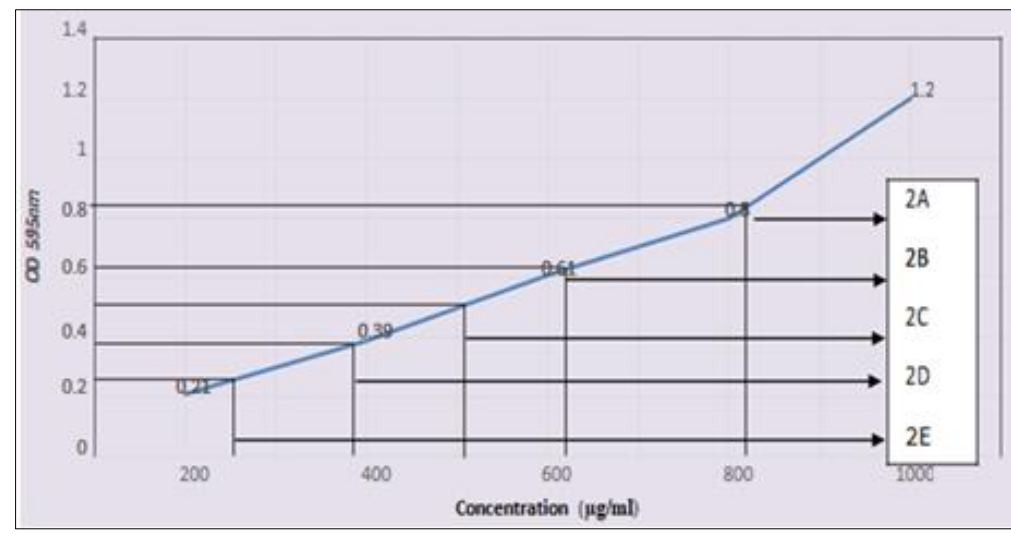

Figure 5. Effect of various nitrogen sources on enzyme Production 2A: casein, 2B: Peptone, 2C: Sodium nitrate, 20D: Urea, 2E: Ammonium sulphate

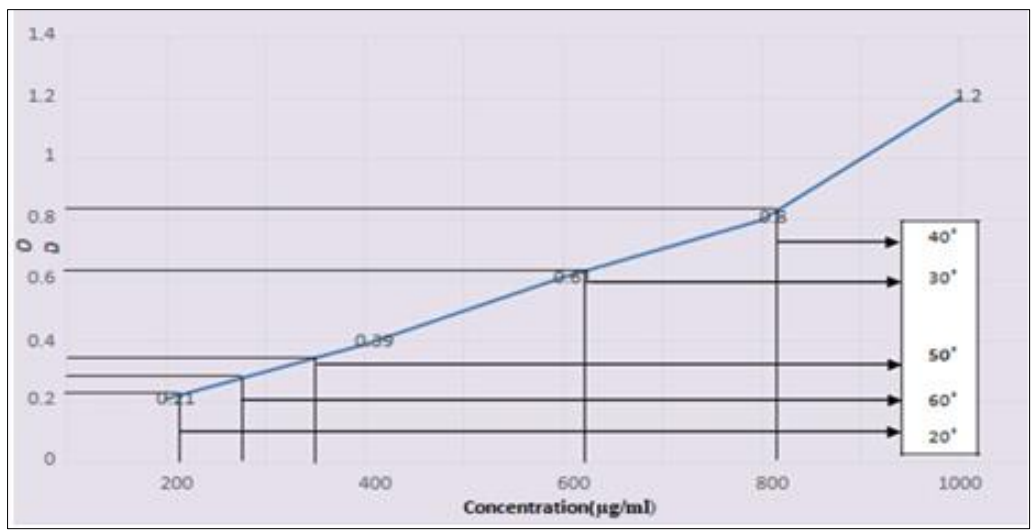

Figure 6. Effect of various temperature of incubation on enzyme production 


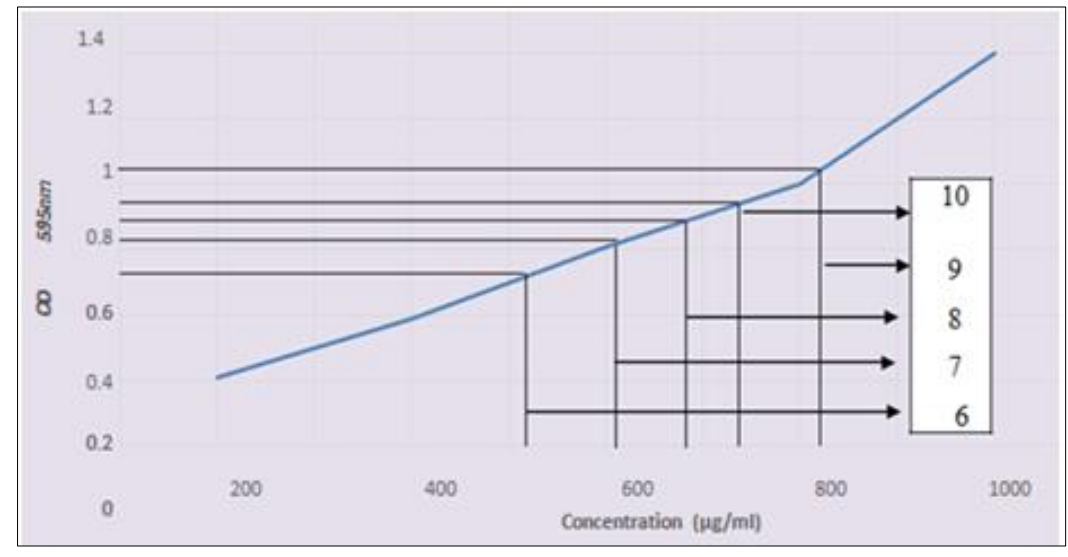

Figure 7. Effect of various $p \mathrm{H}$ of media on enzyme production

Table 2. Standardized media components and conditions for caseinase production from Bacillus subtilis strain DUCC3714

\begin{tabular}{|ccc|}
\hline S. no. & Constituent & Amount for $100 \mathrm{~mL}$ \\
\hline 01 & Glucose & $0.1 \mathrm{gm}$ \\
03 & Yeast extract & $0.05 \mathrm{gm}$ \\
03 & Casein & $0.05 \mathrm{gm}$ \\
04 & $\mathrm{~K}_{2} \mathrm{HPO}_{4}$ & $0.01 \mathrm{gm}$ \\
05 & $\mathrm{MgSO}_{4}$ & $0.02 \mathrm{gm}$ \\
06 & $\mathrm{Na}_{2} \mathrm{CO}_{3}$ & $0.1 \mathrm{gm}$ \\
07 & Distilled water & For dilution upto $100 \mathrm{~mL}$ \\
& Temperature & $40{ }^{\circ} \mathrm{C}$ \\
& $p \mathrm{H}$ & 9 \\
\hline
\end{tabular}

\subsection{Molecular Weight Determination by SDS}

The SDS PAGE picture was shown in Figure 8. Results of our study came resemble with other studies, where bacillus subtilis was appeared resemble with strains of Bacillus thuringiensis with a variety of enzyme capacities, like protease, amylase, esterase, and chitinases [30].

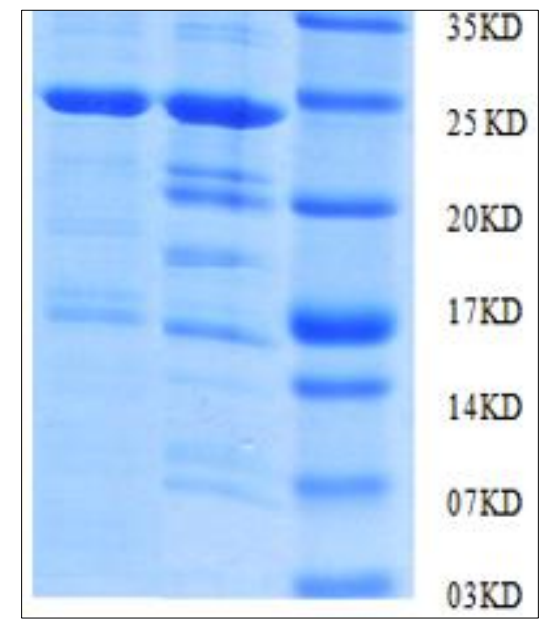

Figure 8. The SDS PAGE picture showing the protein as a thin band in the gel Lane 1: Dialyzed Protein, Lane 2: Crude Protein, Lane 3: Protein marker 


\section{Conclusions}

In the current study a complete analysis of the caseinase enzyme was undertaken which includes, identification of caseinase producers by screening, pure culture preparation, media composition standardization with respect to Nitrogen source and carbon source, standardization of incubation conditions like $p \mathrm{H}$ and temperature. The optimum temperature and $p \mathrm{H}$ for maximum yield of the enzyme was detected to be $40^{\circ} \mathrm{C}$ and $p \mathrm{H} 9$ respectively. The bacteria which were positive for enzyme production was identified using Grams' staining followed by Biochemical characterization and molecular analysis. The bacterium was identified to be Bacillus subtilis strain DUCC3714 using insilico analysis. Thus the above standard composition and incubation conditions can be used for obtaining maximum yield from the bacteria.

\section{References}

1. GHOSH J. S., BARAIE S. S., Int. J. Pharm. Sci. Rev. Res., 35, no. 2, 2015, p. 245.

2. KUMAR N. S., SREEJA D. P. S., NAIR A. S., Int. J. Adv. Res., 4, no. 7, 2016, p. 2048.

3. GHEORGHE G. C., PANTEA O., MATEI V., BOMBOS D., BORCEA A., Rev. Chim., 62(9), 2011, 926.

4. BLASCHEK H. P., SOLBERG M., Journal of Bacteriology, 147, no. 1, 1981, p. 262.

5. TITBALL R. W., BELL A., MUNN C. B., Journal of Infection and Immunity, 49, no. 3, 1985, p.756. 6. CHRISTOPHER A. D., AHMAD A., HENGB Y. L., USUP G., AIP Conference Proceedings, 1571, 2013, p. 202.

7. ***https://catalog.hardydiagnostics.com/cp_prod/Content/hugo/CaseinAgar.html

8. RICHARD JACOBY, MANUELA PEUKERT, ANTONELLA SUCCURRO, ANNA KOPRIVOVA, STANISLAV KOPRIVA, Front Plant Sci., 8, 2017, p. 1617.

9. AVISHAI BEN-DAVID and CHARLES E. DAVIDSON, Journal of Microbiological methods, 107, 2014, p. 214.

10.***https://microbeonline.com/streak-plate-method-principle-purpose-procedure-results/

11.ANDERSON N. L., NOBLE M. A., WEISSFELD A. S., ZABRANSKY R. J., 3B; Quality Systems in the Clinical Microbiology Laboratory, Coordinating editor SEWELL D. L., American Society for Microbiology (ASM), Washington, D.C., 2005.

12.ABOU El-HASSAYEB H. E., ABDEL AZIZ S. M. Z., Int. J. of Curr. Microbio. And Appl. Sci., 5, no. 7, 2016, p. 863.

13.ASHA B., PALANISWAMY M., J. Appl. Pharm. Sci., 8, no. 2, 2018, p.119.

14.PÉREZ BORLA, O., DAVIDOVICH, L. A., ROURA, S. I., LWT Food Science and Technology, 43, no.2, 2009, p. 298.

15.ANN C. SMITH, MARISE A. HUSSEY., Gram stain protocols. American society for microbiology (ASM), 2005, p. 1.

16.***BERGEY'S MANUAL OF DETERMINATIVE BACTERIOLOGY (7th ed.), 54, no. 3, 1964, p. 544.

17.JANIE SIGMON, The starch hydrolysis test, American Society for Microbiology (ASM), 2008.

18.SYLVIA McDevitt, Methyl red and voges-proskauer test protocols, American Society for Microbiology, 2009, p. 1.

19.MAC FADDIN J., Media for Isolation-Cultivation-Identification-Maintenance of Medical Bacteria, Vol. 1, Williams and Wilkins, Baltimore, 1985,

20.JOANNE M. MANNS, SDS - Polyacrylamide Gel Electrophoresis (SDS - PAGE) of Proteins, Current protocols in Microbiology, 2011.

21.SMITH D. R., Methods in Molecular Biology (Clifton, N.J.) 18, 1993, p.433.

22.DEKA A., CHOUGULE B. S., PARVEEN A., LAHAN J. P., BAROOAH M., BORO R. C., Indian Journal of Natural Products and Resources, 6, no. 1, 2015, p. 23.

23.ELLIOTT, W. H., Biochem J., 86, no. 3, 1963, p. 562, PMID: 16748992. 
24.JENNIFER WALKER-DANIELS (jlwd at mail dot iastate dot edu), Iowa State University, United States, 2012.

25.*** https://btiscience.org/wp-content/uploads/2014/04/Sequencer_Manual.pdf.

26.BERG J. M., TYMOCZKO J. L., STRYER L., Lecture Notebook for Biochemistry (6th edition, 1st print. ed.), New York, FREEMAN W. H., 2007.

27.GRZYBOWSKA W., MLYNARCZYK A., MROWKA A., TYSKI S., BUCZKOWSKA T., PAZIK J., DURLIK M., KWIATKOWSKI A., ADAYNSKI L., CHMURA A., PACZEK L., MLYNRCZYK G., Transplantation Proceedings, 41 no. 8, 2009, p. 3256.

28.SEMEDO T., SANTOS M. A., LOPES M. F., MARQUES J. J. F., CRESPO M. T., TENREIRO R., Systematic and Applied Microbiology, 26, no. 1, 2003, p. 13.

29.HUSSEIN A. A., ALI N. A., JASIM H. M., Iraqi J. Biotech, 11, no. 2, 2012, p. 261.

30.TENORIO-SÁNCHEZ S. A., ROJAS-AVELIZAPA N. G., IBARRA J. E., ROJAS AVELIZAPA L. I., CRUZ-CAMARILlO R., Tecnólogy, 3, no. 3, 2010, p. 52.

Manuscript received: 28.08 .2020 